\title{
Nutrition, yield and quality of 'Niagara Rosada' vine fruits using cattle slurry and plastic cover
}

\begin{abstract}
Leonardo Tullio ${ }^{1}$, Heverly Morais ${ }^{2}$, Renato Yagi ${ }^{3}$
Abstract - Plastic cover and organic fertilization for grapevine can bring synergistic benefits in yields and fruit quality. The objective was to characterize and measure the effects of fertilization with cattle slurry in systems without and with plastic cover on plant nutrition, yield and quality of 'Niagara Rosada' fruits. Two experiments were carried out and evaluated in contiguous areas, without and with plastic cover, each one using a randomized complete block design with 4 treatments represented by cattle slurry rates of $0,20,40$ and $60 \mathrm{~m}^{3} \mathrm{ha}^{-1}$, with four replicates. The nutritional status of grapevines was not affected by cattle slurry application without plastic cover in plants growing on fertile sandy soil. Plastic cover provides better nutrition of primary macronutrients and higher yield and fruit quality, even without the use of manure. Without plastic cover, cattle slurry rates above $20 \mathrm{~m}^{3} \mathrm{ha}^{-1}$ and below $60 \mathrm{~m}^{3} \mathrm{ha}^{-1}$ were able to balance phosphate and potassium nutrition in these systems, increasing fruit yield by $31 \%$ up to $32 \mathrm{~m}^{3} \mathrm{ha}^{-1}$, respectively. However, this increment represented $64 \%$ of the average yield of fruits obtained with plastic cover without organic fertilization. Thus, the use of plastic cover on grapevine represents a conservationist soil fertility management, adding sustainability and increasing fruit yield and quality.

Index terms: Vitis sp.; organic fertilizing; plasticulture; conservation agriculture.
\end{abstract}

\section{Nutrição de plantas, produtividade e qualidade de frutos de videira 'Niagara Rosada' com esterco líquido bovino e cobertura plástica}

Corresponding author: nardotullio@hotmail.com

Received: May 29, 2018

Accepted: September 17, 2018

Copyright: All the contents of this journal, except where otherwise noted, is licensed under a Creative Commons Attribution License.

\section{$(\mathrm{cc}) \mathbf{E Y}$}

Resumo - A cobertura plástica e a adubação orgânica para videira podem trazer benefícios sinérgicos na produtividade e na qualidade dos frutos. O objetivo foi caracterizar e mensurar os efeitos da adubação com esterco líquido bovino em sistemas sem e com cobertura plástica, na nutrição das plantas e na produção e qualidade de frutos de 'Niagara Rosada'. Dois experimentos foram conduzidos e avaliados em áreas contíguas, sem e com cobertura plástica, utilizandose em cada qual de delineamento em blocos completamente casualizados com 4 tratamentos, representados por doses de 0;20; 40 e $60 \mathrm{~m}^{3} \mathrm{ha}^{-1}$, com quatro repetições. O status nutricional das videiras não é afetado pela aplicação de esterco líquido bovino sem cobertura plástica, em plantas cultivadas em solo arenoso fértil. A cobertura plástica proporciona melhor nutrição em macronutrientes primários e maior produtividade e qualidade dos frutos, dispensando inclusive $\mathrm{o}$ esterco. Sem cobertura plástica doses de esterco líquido bovino acima de $20 \mathrm{~m}^{3} \mathrm{ha}^{-1} \mathrm{e}$ abaixo de $60 \mathrm{~m}^{3} \mathrm{ha}^{-1}$ podem conciliar nutrições fosfatada e potássica, aumentando a produção de frutos em $31 \%$, com até $32 \mathrm{~m}^{3} \mathrm{ha}^{-1}$, respectivamente. No entanto, este incremento representa $64 \%$ da média de produtividade de frutos obtidos com cobertura plástica sem adubação orgânica. Assim, o uso da cobertura plástica na videira representa um manejo conservacionista da fertilidade do solo, agregando sustentabilidade e incrementando a produtividade e a qualidade dos frutos.

Termos para indexação: Vitis sp.; adubação orgânica; plasticultura; agricultura conservacionista.

\footnotetext{
${ }^{1}$ Agronomist, Master in Conservationist Agriculture, Centro de Ensino Superior dos Campos Gerais, Ponta Grossa-PR. Brazil. E-mail: nardotullio@hotmail.com

${ }^{2}$ Agronomist, PhD in Agronomy, Instituto Agronômico do Paraná, Londrina-PR. Brazil. E-mail: heverly@iapar.br

${ }^{3}$ Agronomist, PhD in Agronomy, Instituto Agronômico do Paraná, Ponta Grossa-PR. Brazil. E-mail: ryagi@iapar.br
} 


\section{Introduction}

'Niagara Rosada' grapevine exports nutrients in the following decreasing order: $\mathrm{K}, \mathrm{N}, \mathrm{P}, \mathrm{Ca}, \mathrm{S}, \mathrm{Mg}, \mathrm{B}, \mathrm{Fe}, \mathrm{Mn}$ and $\mathrm{Zn}$, and the relationship between required quantities and those recommended for primary macronutrients points out the fertilization maintenance performed in vineyards (TECCHIO et al., 2007). On the other hand, mineral fertilization with N, P or K on 'Niagara Rosada' plants without considering soil nutrient availability may not increase fruit yield, production costs and also risk of environmental contamination (TEIXEIRA et al., 2011). In fertile soil, mineral fertilization associated with organic fertilization did not increase yield and quality of 'Solaris' and 'Regente' grapevines; however, mineral fertilization with NPK for the first cultivar increased the incidence of fungal diseases and decreased production (LISEK et al., 2016).

The use of plastic cover has been recommended for organic systems in the Southern region of Brazil, since it reduces the incidence of fungal diseases and increases fruit yield (DETONI et al., 2007; COMIRAN et al., 2012). For 'Rosa Niagara' grapevine production, plastic cover reduces solar radiation on plants, increases daytime air temperature, accelerates sprouting and fruit maturation, and also increases the harvest period, making it more flexible, increasing fruit yield in relation to vineyard without plastic cover (COMIRAN et al., 2012). In contrast, plastic cover increases water availability between lines and decreases it in the superficial layer of planting lines, also decreasing $\mathrm{P}$ and $\mathrm{K}$ concentrations in limbs and leaf petioles (CHAVARRIA et al., 2009). Although lower decomposition rate of organic compost applied to 'Niagara Rosada' grapevine planting lines with plastic cover in relation to its application between planting lines was expected, there are no interactions between these application sites up to rate of $72 \mathrm{Mg} \mathrm{ha}^{-1}$ in the nutritional status and fruit yield and quality (CASALI et al., 2015).

Confined dairy cattle production generates liquid waste that is commonly applied to grain-producing crops. Cattle slurry applications can cause soil sealing and increase water and $\mathrm{P}$ losses through surface runoff, especially when application is preceded by rainfall (MORI et al., 2009), and $\mathrm{N}$ losses by ammonia volatilization without residual incorporation into the soil (BEAUCHAMP et al., 1982). Rates of up to $60 \mathrm{~m}^{3} \mathrm{ha}^{-1}$ applied at least five days before intense rains allow adequate infiltration of the cattle slurry into clay soil (CHEROBIM et al., 2015). In this type of soil, cattle slurry applications of up to $90 \mathrm{~m}^{3} \mathrm{ha}^{-1}$ year-1 for six years provided provided linear increases of $\mathrm{Ca}, \mathrm{Mg}$ and $\mathrm{P}$ in the 0 to $5 \mathrm{~cm}$ layer, of organic $\mathrm{C}$ at 5 to $10 \mathrm{~cm}$ depth and of $\mathrm{K}$ up to $80 \mathrm{~cm}$ depth in the 0 to $5 \mathrm{~cm}$ layer, organic $\mathrm{C}$ at 5 to $10 \mathrm{~cm}$ depth and $\mathrm{K}$ up to $80 \mathrm{~cm}$ depth
(BARCELLOS et al., 2015).

On the other hand, cattle slurry application may have another behavior in soil maintained under plastic cover. Under plastic cover, the following occurs: less water availability in superficial layers (MOTA et al., 2009), higher daytime maximum temperatures (CARDOSO et al., 2008; COMIRAN et al., 2012) and lower relative humidity and evapotranspiration (CARDOSO et al., 2008). Thus, the objective was to evaluate cattle slurry application in 'Niagara Rosada' vineyards (Vitis labrusca L.) without or with plastic cover, in terms of plant nutrition and fruit quality and yield.

\section{Material and Methods}

The experiment was performed in the municipality of Ponta Grossa, PR, Brazil (2519'41.61 "S, 50¹2'18.09”W and 859 meters a.s.1.), in the period from September 2014 to February 2015. According to the Köppen-Geiger climate classification, the climate is $\mathrm{Cfb}$, described as subtropical, humid, mesothermic and with no defined dry season, in which the average temperature in the coldest month is $13.8^{\circ} \mathrm{C}$ (July) and $21.4^{\circ} \mathrm{C}$ (January), with average annual precipitation of $1554 \mathrm{~mm}$ (IAPAR, 2018).

The soil is classified as Haplic Cambisol (EMBRAPA, 2013) or as Inceptisol (SOIL SURVEY STAFF, 2014), sandy textural class with $670 \mathrm{~g} \mathrm{~kg}^{-1}$ of sand, $230 \mathrm{~g} \mathrm{~kg}^{-1}$ of clay and $10 \mathrm{~g} \mathrm{~kg}^{-1}$ of silt in the $0-20$ $\mathrm{cm}$ depth (EMBRAPA, 1997). The soil was chemically characterized (PAVAN et al., 1992) in the $0-10 \mathrm{~cm}$ and $10-20 \mathrm{~cm}$ (Table 1), presenting very high $\mathrm{P}, \mathrm{K}, \mathrm{Ca}$ and $\mathrm{Mg}$ levels and high organic $\mathrm{C}$, according to interpretation classes of the Fertilization and Liming Manual for the State of Paraná (NEPAR-SBCS, 2017).

A 'Niagara Rosada' vineyard (Vitis labrusca L.) was evaluated, planted in 2011 on 'Riparia do Traviu' (Vitis riparia) rootstock, performed in Y system with spacing of $1 \mathrm{~m}$ between plants and $3 \mathrm{~m}$ between rows, totaling 3,333 plants ha-1. Two experiments were carried out, with plastic cover and without plastic cover, each one in a randomized complete block design, with four treatments represented by cattle slurry rates $(0,20,40$ and $60 \mathrm{~m}^{3} \mathrm{ha}^{-1}$ ) and four replicates. The slurry used came from the monthly stable washing with confined cattle fed with feed, corn silage and mineral salt. Stored in reservoir with propeller structure coupled for the effluent homogenization, cattle slurry presented $24.2 \%$ dry matter, $1.4 \mathrm{~g} \mathrm{~L}^{-1} \mathrm{~N}, 0.99 \mathrm{~g} \mathrm{~L}^{-1} \mathrm{P}$ and $1.02 \mathrm{~g} \mathrm{~L}^{-1} \mathrm{~K}$.

In experiment with plastic cover, the grapevine planting lines were covered with 150 microns thick transparent braided polyethylene plastic, positioned on plants in pyramidal form, reaching one meter above the canopy in the central part of the structure. In both experiments, pruning was carried out on September 9, 
2014 and about ten days later, cattle slurry was applied at the beginning of the sprouting season, dividing the effluent volume according to the respective treatment into eight equal parts with the objective of evenly distributing the cattle slurry rate over the plot area. Treatments were carried out according to technical recommendations for the region and according to the culture needs, which were distinct in each experiment. Agrochemical applications were made to control mildew (Plasmopara viticola) and anthracnose (Colletotrichum dematium), in a total of seven applications in system without plastic cover and eight with plastic cover.

Sixty-two days after cattle slurry applications in both experiments, 10 leaves per plot were collected in the lowest portion of grapevines for estimations of chlorophyll A, B and total indexes using Falker ${ }^{\circledR}$ chlorophyllometer. From the second fortnight of January to the second fortnight of March 2015, fruits present in the four central plants of each plot were harvested based on the point of visual maturation and damaged berries of each cluster were discarded. Then, bunches of each plot were counted and weighed, separating 10 bunches per plot for weighing and estimates of bunch weight and total soluble solids ( $\left.{ }^{\circ} \mathrm{Brix}\right)$ in berries of the apical, median and basal portions of each cluster by means of manual portable refractometer. After the fruit harvest period, 10 leaves (limbus + petiole) were collected per plot, being washed, dried in oven with forced air circulation at about $65^{\circ} \mathrm{C}$ until constant weight and chemically analyzed for $\mathrm{N}, \mathrm{P}, \mathrm{K}, \mathrm{Ca}$ and $\mathrm{Mg}$ according to procedures described in Miyazawa et al. (2009).

A ratio of less than seven among residual mean squares of both experiments with identical experimental designs (BANZATO and KRONKA, 1995) was adopted as a prerequisite for the joint analysis of experiments. Quantitative factors, cattle slurry rates, were evaluated using $5 \%$ polynomial regressions and $1 \%$ probability in both experiments. Student's t-tests at $5 \%$ probability were applied in the comparison among results without and with plastic cover in each cattle slurry rate in case of significant interactions $(p<0.05)$. Pearson correlations at $5 \%$ of probability were calculated between dependent variables, unfolding the treatments. Statistical analyses were performed using Agroestat software (BARBOSA and MALDONADO Jr., 2009).

\section{Results and Discussion}

There was no effect of cattle slurry rates on $\mathrm{N}, \mathrm{P}$ and $\mathrm{K}$ concentrations in diagnostic leaves and indirect in chlorophyll measurements (ICF) regardless of grapevine management system, with or without plastic cover, with no interactions $(p<0.05)$ between experiments and cattle slurry rates for these variables (Figure 2). In this case, very high (NEPAR-SBCS, 2017) organic C, P and K levels in the soil surface layer (Table 1) and the organic fertilization did not result in higher absorption. N, P and $\mathrm{K}$ concentrations of 'Niagara Rosada' grapevine leaves were not affected by up to $72 \mathrm{~L} \mathrm{plant}^{-1}$ year ${ }^{-1}$ of organic compost for two years, regardless of whether applied to rows or between rows (CASALI et al., 2015), or, with $20 \mathrm{~m}^{3} \mathrm{ha}^{-1}$ year ${ }^{-1}$ of organic compost applied over three years, always on the same side of the crop row, on alternate sides over the years, on both sides or in pits (MELO et al., 2012).

At $20-40 \mathrm{~m}^{3} \mathrm{ha}^{-1}$ cattle slurry, approximately 20 to $40 \mathrm{~kg} \mathrm{ha}^{-1}$ of $\mathrm{P}_{2} \mathrm{O}_{5}$ and $\mathrm{K}_{2} \mathrm{O}$ were respectively applied. These amounts would be made available according to maintenance fertilization recommendations for grapevines grown in soils with very high $\mathrm{P}$ and $\mathrm{K}$ levels, with expected fruit yield below $12 \mathrm{Mg} \mathrm{ha}^{-1}$ (NEPAR-SBCS, 2017), which was verified in both experiments, without and with plastic cover. In soils rich in $\mathrm{P}$ and $\mathrm{K}$, in addition to the fact that there are no responses of 'Niagara Rosada' grapevine to mineral fertilization levels and fertilization with poultry litter after pruning, low $\mathrm{P}$ and $\mathrm{K}$ rates were sufficient to maintain nutrient contents after four production cycles (TEIXEIRA et al., 2011).

In general, foliar P (Figure 2b) and $\mathrm{K}$ (Figure 2c) concentrations were higher in experiment with plastic cover compared to experiment without plastic cover, on average $24.3 \%$ and $12.7 \%$, respectively, but significantly higher $(p<0.05)$ only at certain rates for both nutrients. These results are not consistent with those obtained by Chavarria et al. (2009), who observed decreases in P and $\mathrm{K}$ concentrations in petioles and leaf limbs with plastic cover compared to uncovered vineyard, due to the lower water availability in 'Moscato Giallo' grapevine planting rows. Appropriate foliar N, P and $\mathrm{K}$ concentrations for grapevine are respectively $30-35 \mathrm{~g} \mathrm{~kg}^{-1} ; 2.4-2.9 \mathrm{~g} \mathrm{~kg}^{-1}$ and $15-20 \mathrm{~g} \mathrm{~kg}^{-1}$ (BOARETTO et al., 2009). Foliar N, $\mathrm{P}$ and $\mathrm{K}$ levels observed in the present work are adequate for $\mathrm{P}$ and below the reference values for $\mathrm{N}$ and $\mathrm{K}$, which emphasize the care with the leaching of these nutrients in sandy soils.

With cattle slurry application in sandy soil, probably there was no pore sealing with increased soil and P losses and water flow on the surface, as observed in clayey soils (MORI et al., 2009). There is no need for cattle slurry application at least five days before rain for adequate infiltration of rates of up to $60 \mathrm{~m}^{3} \mathrm{ha}^{-1}$ in clayey soils (CHEROBIM et al., 2015). However, N, P and K leaching can occur in sandy soil without plastic cover. The $\mathrm{N}$ amounts immobilized with the application of cattle slurry are inversely proportional to the soil clay content (SORENSEN and JENSEN, 1995), and nitrate leaching can still occur in clay soil with cattle slurry application, in addition to $\mathrm{P}$ and $\mathrm{K}$ losses but within acceptable levels (PIOVESAN et al., 2009). In clay soil, cattle slurry applications up to $90 \mathrm{~m}^{3} \mathrm{ha}^{-1}$ year ${ }^{-1}$ for six years provided linear $\mathrm{Ca}, \mathrm{Mg}$ and $\mathrm{P}$ increases in the $0-5 \mathrm{~cm}$ layer, 
organic $\mathrm{C}$ at 5 to $10 \mathrm{~cm}$ depth and $\mathrm{K}$ up to $80 \mathrm{~cm}$ depth (BARCELLOS et al., 2015). Despite reducing the water availability in soil superficial layers (CHAVARRIA et al., 2009; MOTA et al., 2009), an excess of more than 250 $\mathrm{mm}$ of rainfall after cattle slurry application was observed, considering the historical average of 30 years (Fig. 1). This may justify the conservationist effect of the plastic cover on the increase of foliar P concentrations and correlation $\left(\mathrm{r}=0.69^{* *}\right)$ among foliar $\mathrm{P}$ and $\mathrm{K}$ concentrations in experiment with plastic cover (Table 2).

The highest $\mathrm{P}$ levels were observed in the lowest cattle slurry levels, in the control treatment, with application of $20 \mathrm{~m}^{3} \mathrm{ha}^{-1}$ (Figure 2b) and the highest $\mathrm{K}$ levels with maximum cattle slurry rate of $60 \mathrm{~m}^{3} \mathrm{ha}^{-1}$ in relation to uncovered vineyard (Figure 2c). In experiment with plastic cover, $\mathrm{P}$ concentrations $36.2 \%$ higher $(p<0.05)$ in the two lowest cattle slurry rates and $\mathrm{K}$ concentration $20.5 \%$ higher $(p<0.05)$ in the highest cattle slurry rate applied indicated antagonistic effects of the interaction between plastic cover and fertilization with cattle slurry for these nutrients. Above $20 \mathrm{~m}^{3} \mathrm{ha}^{-1}$, the plastic cover did not affect the phosphorus content of 'Niagara Rosada' grapevines, since in experiment without plastic cover, probably there was $\mathrm{P}_{2} \mathrm{O}_{5}$ supply from 40 to $60 \mathrm{~kg} \mathrm{ha}^{-1}$, with the two highest cattle slurry rates evaluated. On the other hand, with less than $60 \mathrm{~kg} \mathrm{ha}^{-1}$ of $\mathrm{K}_{2} \mathrm{O}$ via cattle slurry, there were no differences among leaf $\mathrm{K}$ concentrations between experiments without and with plastic cover. This indicates that amounts higher than this can be lost by leaching in vineyards without plastic cover. Foliar K concentrations were higher $(p<0.05)$ under adequate water availability regime in relation to soils with water deficit, and even when the application of $\mathrm{K}$ exceeds the amounts extracted from the nutrient, greater availability of $\mathrm{K}$ in the soil can increase the foliar concentration of this nutrient (LEIBAR et al., 2017). However, the average $\mathrm{N}$ (Figure $2 \mathrm{a}$ ) and $\mathrm{K}$ concentrations (Figure $2 \mathrm{c}$ ) were below levels considered suitable for vines in the flowering stage, which are from 30 to $35 \mathrm{~g} \mathrm{~kg}^{-1} \mathrm{~N}$ and 15 to $20 \mathrm{~g} \mathrm{~kg}^{-1} \mathrm{~K}$ (NEPAR-SBCS, 2017).

There were no differences between vineyard control systems, without or with plastic cover, and the effect of cattle slurry rates on leaf $\mathrm{N}$ concentration (Figure 2a) and indirect chlorophyll measurement (ICF) values in both experiments (Figure 2d). There were no correlations between leaf $\mathrm{N}$ concentrations and ICF measurements in both experiments (Table 2). Mota et al. (2009) observed higher $(p<0.05) \mathrm{A}, \mathrm{B}$ and total chlorophyll levels among covered 'Cabernet Sauvignon' plants in relation to plants without plastic cover, in only one of four evaluations. However, Chavarria et al. (2012) observed higher total chlorophyll levels in 'Moscato Giallo' grapevines kept under plastic cover at two evaluation periods during flowering and after fruit harvest. The results of the present work can be related to the short period between time of cattle slurry application and ICF measurements performed about 2 months after, as well as eventual $\mathrm{N}$ losses by nitrate leaching and ammonia volatilization. With the application of cattle slurry rates, leaching of nitrate contents above those applied by manure was observed, which were also above the limit allowed by Brazilian legislation (PIOVESAN et al., 2009). According to the authors, underestimation of the nitrate levels in the cattle slurry using the analytical method and nitrification of ammonium from cattle slurry can justify the high levels of nitrate found in solution percolated through $40 \mathrm{~cm}$ of sample column. However, it is necessary to incorporate liquid dairy cattle manure to avoid ammonia volatilization in the first week after effluent application (BEAUCHAMP et al., 1982).

At all cattle slurry rates, even in treatment without fertilization, fruit yields were higher $(p<0.05)$ under plastic cover (Figure 3c). Only without plastic cover, effect of cattle slurry rates on 'Niagara Rosada' fruit yield was observed, and there was a quadratic effect with maximum technical efficiency of $32 \mathrm{~m}^{3} \mathrm{ha}^{-1}$ for maximum yield of $12.745 \mathrm{~kg} \mathrm{ha}^{-1}$ of fruits. This fruit yield corresponded to an increase of $3,028 \mathrm{~kg} \mathrm{ha}^{-1}(31.2 \%)$ in relation to control without fertilization and generated the smallest difference in relation to the average yield obtained with plastic cover, of $38.8 \%$. Casali et al. (2015) observed quadratic effects of organic compost rates in the number of bunches per plant and in fruit yield, regardless of fertilizer application in 'Niagara Rosada' grapevine. In the present work, the yield of 'Niagara Rosada' fruits without plastic cover was correlated to foliar $\mathrm{P}\left(\mathrm{r}=0.51^{*}\right)$ and $\mathrm{K}$ concentrations ( $\mathrm{r}$ $\left.=0.60^{*}\right)$, unlike that observed in experiment with plastic cover, where such correlations were observed (Table 2). Tecchio et al. (2006) did not observe significant correlations between nutrient foliar concentrations and yield of 'Niagara Rosada' fruits implanted in 'Riparia do Traviú' rootstock, the same one used in the present study. However, when implanted in IAC 766 rootstock, the same authors observed correlations between yields obtained and foliar $\mathrm{K}$ concentrations $(\mathrm{r}=0.42 *)$ and $\mathrm{K}$ contents in soil samples of planting rows $\left(\mathrm{r}=0.48^{*}\right)$, and between planting rows $\left(\mathrm{r}=0.56^{* *}\right)$.

Higher number of bunches per plant $(46.3 \%$ on average, Figure $3 \mathrm{~b})$ and higher total solid contents (7\% on average, Figure 3d) were observed in experiment with plastic cover in relation to experiment without plastic cover. There was a quadratic effect of cattle slurry rates on the average weight of bunches under plastic cover, reaching rate of maximum technical efficiency of 31.4 $\mathrm{m}^{3} \mathrm{ha}^{-1}$ for maximum average bunch weight of $219 \mathrm{~g}$. Increases $(p<0.05)$ of $28.8 \%$ and $25.8 \%$ in the average weight of bunches with plastic cover in relation to those without plastic cover were observed at rates of 20 and 60 $\mathrm{m} \mathrm{ha}^{-1}$, respectively. Detoni et al. (2007) observed that 'Cabernet Sauvignon' grapevines growing under plastic 
cover presented increases of $110.0 \%$ in the number of bunches per plant and $71.4 \%$ in bunch weight in relation to plants without plastic cover, although the authors did not observe differences $(p>0.05)$ for total soluble solids. On the other hand, Chavarria et al. (2009) did not observe differences $(p>0.05)$ between weight and number of bunches of 'Moscato Giallo' plants as a function of the presence of plastic cover or not. In the present work, the highest yields of 'Niagara Rosada' fruits are justified by the increase in the average weight of bunches, which can be interesting for fresh consumption. Correlations between fruit yields and number of bunches were observed in both experiments, without $\left(\mathrm{r}=0.79^{* *}\right)$ and with plastic cover $(\mathrm{r}$ $\left.=0.81^{* *}\right)$, but correlation $\left(\mathrm{r}=0.67^{* *}\right)$ between fruit yields and the bunch rootstock was observed only in experiment with plastic cover (Table 2).

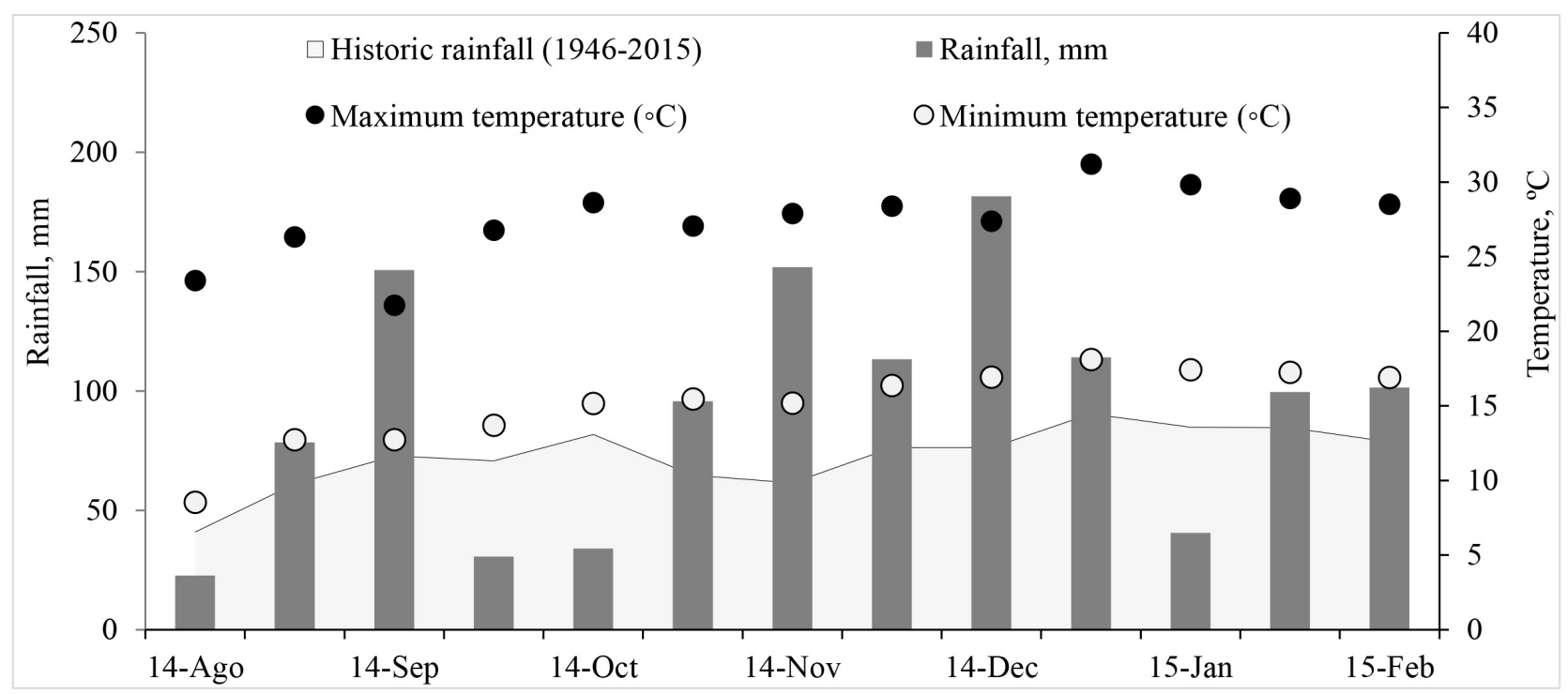

Figure 1 - Rainfall during experimentation and historical averages (1946 - 2015) and maximum and minimum temperatures during the experimental period. Ponta Grossa, Paraná, Brazil.

Table 1 - Chemical characterization of the experimental area soil.

\begin{tabular}{lcccccccccc}
\hline Layer & $\begin{array}{c}\mathrm{P} \\
\mathrm{mg} \mathrm{dm}^{-3}\end{array}$ & $\begin{array}{c}\mathrm{C} \\
\mathrm{g} \mathrm{dm}^{-3}\end{array}$ & $\mathrm{pH}$ & $\mathrm{H}+\mathrm{Al}$ & $\mathrm{Ca}$ & $\mathrm{Mg}$ & $\mathrm{K}$ & $\mathrm{SB}$ & $\mathrm{T}$ & $\mathrm{V}$ \\
& 44.42 & 22.60 & 5.98 & 3.87 & 5.52 & 4.09 & 0.94 & 10.55 & 14.42 & 73.21 \\
\hline $0-10 \mathrm{~cm}$ & 14.62 & 18.98 & 6.01 & 3.71 & 5.10 & 3.91 & 0.69 & 9.70 & 13.41 & 72.28 \\
$10-20 \mathrm{~cm}$ & $14 .--\mathrm{cmol}_{\mathrm{c}} \mathrm{dm}^{-3}$ & & &
\end{tabular}

*H + Al: SMP buffer solution; exchangeable Al, Ca and Mg: KCl 1 mol L-1; P and K: Mehlich-1; Organic C: Walkley \& Black; SB: Sum of Bases; T: Cation exchange capacity; V\%: Base saturation index. 

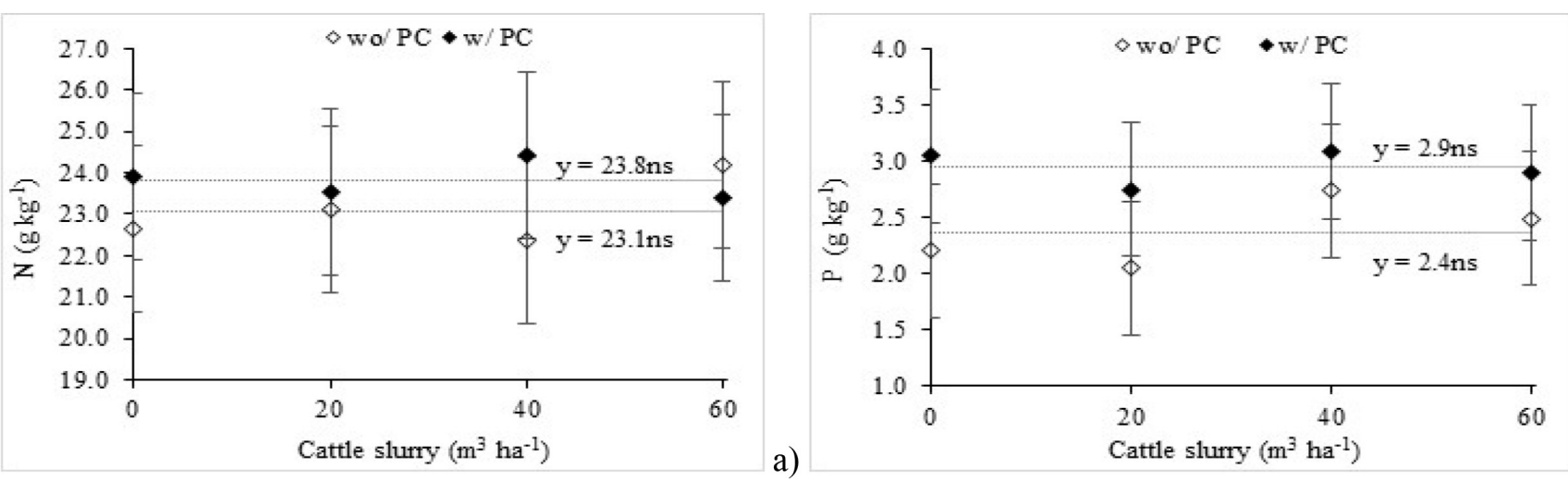

b)
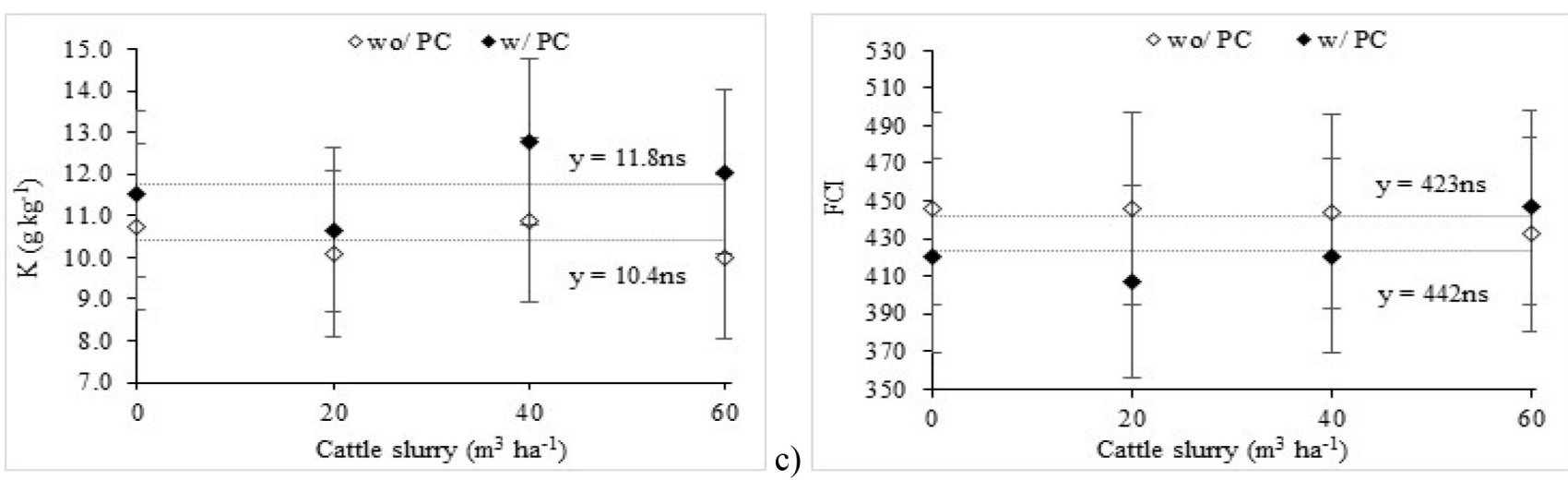

d)

Figure 2 - N (a), P (b) and K (c) contents on leaves and Falker chlorophyll index (d) as a function of cattle slurry rates in experiments without (wo/PC) and with (w/PC) plastic cover. Vertical bars indicate a significant minimal difference extension $(p<0.05)$ among experiments in each cattle slurry rate in case of interaction $(p<0.05)$. Equal letters, in parentheses, indicate absence of significant difference $(p<0.05)$ between mean values for experiments with and without plastic cover. Ns: not significant.

Table 2 - Pearson linear correlations ( $p<0.05$ ) for fruit yield (FY), number of bunches (NB), mean bunch weight (MBW), total soluble solids ( ${ }^{\circ}$ Brix), nitrogen $(\mathrm{N})$ phosphorus $(\mathrm{P})$ and potassium $(\mathrm{K})$ in diagnostic leaves and Falker chlorophyll index values (FCI) in experiments with and without plastic cover fertilized with cattle slurry rates (Ponta Grossa, Paraná, Brazil, 2016).

\begin{tabular}{|c|c|c|c|c|c|c|c|c|}
\hline Variable & FY & NB & MBW & ${ }^{\circ}$ Brix & $\mathrm{N}$ & $\mathrm{P}$ & $\mathrm{K}$ & FCI \\
\hline \multicolumn{9}{|c|}{ 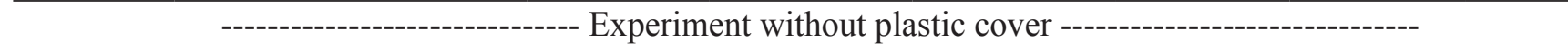 } \\
\hline FY & - & - & - & - & - & - & - & - \\
\hline NB & $0.79 * *$ & - & - & - & - & - & - & - \\
\hline MBW & $0.44 \mathrm{~ns}$ & $-0.18 \mathrm{~ns}$ & - & - & - & - & - & - \\
\hline${ }^{\circ}$ Brix & $-0.08 \mathrm{~ns}$ & $-0.05 \mathrm{~ns}$ & $-0.05 \mathrm{~ns}$ & - & - & - & - & - \\
\hline $\mathrm{N}$ & $-0.16 n s$ & $-0.30 \mathrm{~ns}$ & $0.44 \mathrm{~ns}$ & $0.31 \mathrm{~ns}$ & - & - & - & - \\
\hline $\mathrm{P}$ & $0.51 *$ & $0.46 \mathrm{~ns}$ & $0.11 \mathrm{~ns}$ & $-0.31 \mathrm{~ns}$ & $0.21 \mathrm{~ns}$ & - & - & - \\
\hline K & $0.60 *$ & $0.38 \mathrm{~ns}$ & $0.38 \mathrm{~ns}$ & $-0.05 \mathrm{~ns}$ & $0.15 \mathrm{~ns}$ & $0.42 \mathrm{~ns}$ & - & - \\
\hline FCI & $0.25 \mathrm{~ns}$ & $0.20 \mathrm{~ns}$ & $0.12 \mathrm{~ns}$ & $-0.38 \mathrm{~ns}$ & $-0.28 \mathrm{~ns}$ & $-0.02 \mathrm{~ns}$ & $-0.13 n s$ & - \\
\hline \multicolumn{9}{|c|}{ 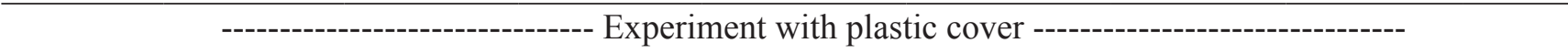 } \\
\hline FY & - & - & - & - & - & - & - & - \\
\hline NB & $0.81 * *$ & - & - & - & - & - & - & - \\
\hline MBW & $0.67 * *$ & $0.12 \mathrm{~ns}$ & - & - & - & - & - & - \\
\hline${ }^{\circ}$ Brix & $-0.15 \mathrm{~ns}$ & $-0.30 \mathrm{~ns}$ & $0.13 \mathrm{~ns}$ & - & - & - & - & - \\
\hline $\mathrm{N}$ & $0.46 \mathrm{~ns}$ & $-0.27 \mathrm{~ns}$ & $-0.42 \mathrm{~ns}$ & $0.29 \mathrm{~ns}$ & - & - & - & - \\
\hline $\mathrm{P}$ & $-0.22 \mathrm{~ns}$ & $0.06 \mathrm{~ns}$ & $-0.49^{*}$ & $-0.13 n s$ & $0.29 \mathrm{~ns}$ & - & - & - \\
\hline $\mathrm{K}$ & $-0.16 \mathrm{~ns}$ & $0.11 \mathrm{~ns}$ & $-0.46 n s$ & $-0.19 n s$ & $0.04 \mathrm{~ns}$ & $0.69 * *$ & - & - \\
\hline FCI & $0.53 *$ & $0.54^{*}$ & $0.54 *$ & $-0.03 \mathrm{~ns}$ & $-0.37 \mathrm{~ns}$ & $0.04 \mathrm{~ns}$ & $-0.07 \mathrm{~ns}$ & - \\
\hline
\end{tabular}

**. * e ns: Significant at $1 \%$ and $5 \%$ probability and not significant, respectively. 

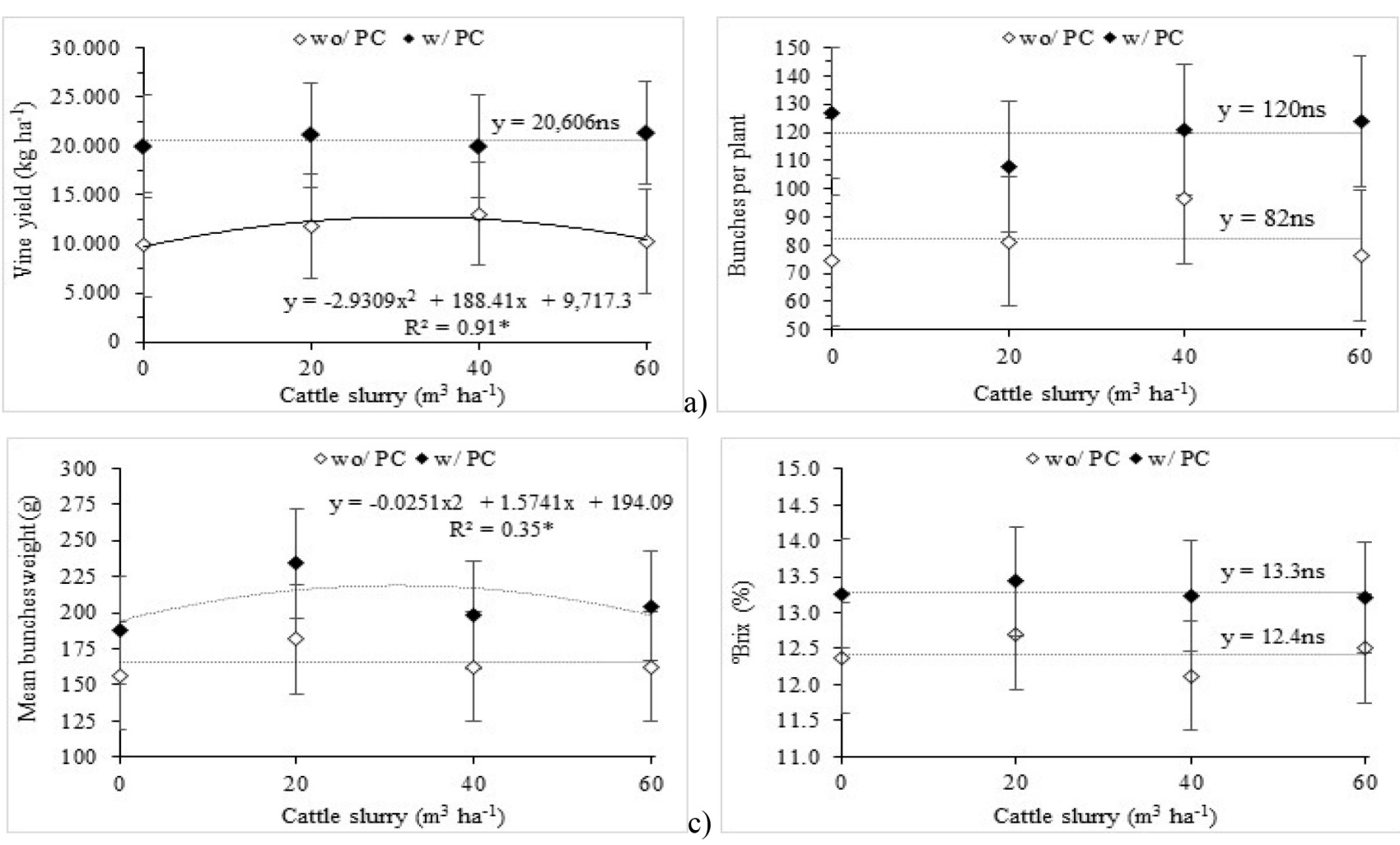

b)

Figure 3 - Bunches per plant, mean bunch weights, fruit yield and total soluble solids ( ${ }^{\circ}$ Brix) as a function of cattle slurry rates in experiments without (wo/CP) and with (w/CP) plastic cover. Vertical bars indicate a significant minimal difference extension $(p<0.05)$ among experiments in each cattle slurry rate in case of interaction $(p<0.05)$. Differential letters in parentheses indicate significant difference $(p<0.05)$ among mean values for experiments with and without plastic cover. ns $e^{*}$ not significant and significant at $5 \%$ probability, respectively.

\section{Conclusions}

The nutritional status of 'Niagara Rosada' vines is not affected by cattle slurry application in vineyards grown in fertile sandy soil without or with plastic cover. In this soil, plastic cover provides better supply of primary macronutrients and higher fruit yield and quality, even avoiding cattle slurry fertilization. In uncovered grapevine, cattle slurry doses above $20 \mathrm{~m}^{3} \mathrm{ha}^{-1}$ and below $60 \mathrm{~m}^{3} \mathrm{ha}^{-1}$ are able to balance phosphate and potassium nutrition in these systems, respectively, increasing fruit yields by $31 \%$ up to $32 \mathrm{~m}^{3} \mathrm{ha}^{-1}$. However, this increment represented $64 \%$ of the average fruit yield obtained with plastic cover without organic fertilization. Thus, the use of plastic cover in 'Niagara Rosada' grapevines represents a conservationist management of soil fertility, adding sustainability and increasing fruit yield and quality.

\section{References}

BANZATTO, D.A.; KRONKA, S.N. Experimentação agrícola. 3.ed. Jaboticabal: Editora Funep, 1995. 247p.

BARBOSA J.C.; MALDONADO JÚNIOR, W. Software AgroEstat - sistema de análises estatísticas de ensaios agronômicos. Jaboticabal: FCAV, Universidade Estadual Paulista, 2009. 396p.

BARCELLOS, M.; MOTTA, A.C.V.; PAULETTI, V., SILVA, J.C.P.M.; ZIMMER, J. Atributos químicos de Latossolo sob plantio direto adubado com esterco de bovinos e fertilizantes minerais Comunicata Scientiae, Piauí, v.6, n.3, p.263-273, 2015.

BEAUCHAMP, E.G.; KIDD, G.E.; THURTELL, G. Ammonia volatilization from liquid dairy cattle manure in the field. Canadian Journal of Soil Science, Alberta, v.62, n.1, p.1-19, 1982. 
BOARETTO,A.E.; RAIJ, B.V.; SILVA, F.C.; CHITOLINA, C.; TEDESCO, M.J.; Carmo, C.A.F.S. Amostragem acondicionamento e preparo de amostras de plantas para análise química. Brasília, DF: Embrapa, 2009. p.59-86. (Informação Tecnológica, 2).

CARDOSO, L.S.; BERGAMASCHI, H.; COMIRAN, F.; CHAVARRIA, G.; MARODIN, G.A.B; DALMAGO, G.A.; SANTOS, H.P.; MANDELI, F. Alterações micrometeorológicas em vinhedos pelo uso de coberturas de plástico. Pesquisa Agropecuária Brasileira, Brasília, DF, v.43, n.4, p.441-447, 2008.

CASALI, A.V.; MEURER, E.J.; MELO, G.W.B.D.; AMBROSINI, V.G.; COUTO, R.D.R.; BRUNETTO, G. Estado nutricional, produção e composição das uvas de Niágara Rosada submetidas à aplicação de composto orgânico. Revista de Ciências Agrárias, Recife, v.58, n.3, p.257-262, 2015.

CHAVARRIA, G.; SANTOS, H.P.; CASTRO, L.A.S.; MARODIN, G.A.B.; BERGAMASCHI, H. Anatomy, chlorophyll content and photosynthetic potential in grapevine leaves under plastic cover. Revista Brasileira de Fruticultura, Jaboticabal, v.34, n.3, p.661-668, 2012.

CHAVARRIA, G.; SANTOS, H.P.D.; MELO, G.W.B.; BRUNETTO, G.; SILVA, L.C. Influência da cobertura plástica na disponibilidade de água no solo e na concentração de macronutrientes em folhas de videiras. Synergimus Scientifica, Pato Branco, v.4, n., p.1-3, 2009.

CHEROBIM, V.F.; FAVARETTO, N.; ARMINDO R.A.; BARTH, G.; DIECKOW, J.; PAULETTI, V. Water infiltration post-liquid dairy manure application in notill Oxisol of Southern Brazil. Soil Tillage Research, Amsterdam, v.153, n.1, p.104-111, 2015.

COMIRAN, F.; BERGAMASCHI, H.; HECKLER, R.M.M.; SANTOS, H.P.; ALBA, D.; SARETTA E. Microclima e produção de videiras 'Niágara Rosada' em cultivo orgânico sob cobertura. Revista Brasileira de Fruticultura, Jaboticabal, v.34, n.1, p.152-159, 2012.

DETONI, A.M.; CLEMENTE, E.; FORNARI, C. Produtividade e qualidade da uva 'Cabernet Sauvignon' produzida sob cobertura de plástico em cultivo orgânico. Revista Brasileira de Fruticultura, Jaboticabal,v.29, n.3, p.530-534, 2007.
EMBRAPA- Empresa Brasileira de Pesquisa Agropecuária. Sistema brasileiro de classificação de solos. 3 . ed. Brasília, DF, 2013. 353p.

EMBRAPA- Empresa Brasileira de Pesquisa Agropecuária. Manual de métodos de análise de solos. Rio de Janeiro, 1997. 212.

IAPAR - Instituto Agronômico do Paraná. Média dos dados climáticos de Ponta Grossa (2014-2015). Londrina, 2015. (Informativo online). Disponível em: $<$ http://www.iapar.br/pagina-1828.html >. Acesso em: 01 maio 2018.

LEIBAR, U.; PASCUAL, I.; AIZPURUAL, A.; MORALES, F.; UNAMUNZAGA, O. Grapevine nutritional status and $\mathrm{K}$ concentration of must under future expected climatic conditions texturally different soils. Journal of Soil Science and Plant Nutrition, Temuco, v.17, n.2, p.385-397, 2017.

LISEK, J.; SAS-PASZT, L.; DERKOWSKA, E.; MROWICKI, T.; PRZYBYL, M.; FRAC, M. Growth, yielding and healthiness of grapevine cultivars 'Solaris' and 'Regent' in response to fertilizers and biostimulants. Journal of Horticultural Research, Skierniewice, v.24, n.2, p.49-60, 2016.

MELO, G.W.B.; BRUNETTO, G.; BASSO, A.; HEINZEN, J. Resposta das videiras a diferentes modos de distribuição de composto orgânico no solo. Revista Brasileira de Fruticultura, Jaboticabal, v.34, n.2, p.493-503, 2012.

MIYAZAWA, M.; PAVAN, M.A.; MURAOKA, T.; CARMO, C.A.F.S.; MELLO, W.J. Análise química de tecido vegetal. In: SILVA, F.C. (Ed.). Manual de análises químicas de solos, plantas e fertilizantes. 2.ed. Rio de Janeiro: Embrapa Solos, 2009. p.191-233.

MORI, H.F.; FAVARETTO, N.; PAULETTI, V.; DIECKOW, J.; SANTOS, W. L. Perda de água, solo e fósforo com aplicação de dejeto líquido bovino em Latossolo sob plantio direto e com chuva simulada. Revista Brasileira de Ciência do Solo, Viçosa, MG, v.33, n.1, p.189-198, 2009.

MOTA, C.S.; AMARANTE, C.V.T.; SANTOS, H.P.; ZANARDI, O.Z. Comportamento vegetativo e produtivo de videiras Cabernet Sauvignon cultivadas sob cobertura plástica. Revista Brasileira de Fruticultura, Jaboticabal, v.30, n.2, p.148-153, 2009. 
NEPAR-SBCS - Núcleo Estadual Paraná-Sociedade Brasileira de Ciência do Solo. Manual de adubação e calagem para o Estado do Paraná. Curitiba: SBCS/ NEPAR, 2017. 482p.

PAVAN, M.A.; BLOCH, M.D.M.; ZEMPULSKI, H.C.; MIYAZAWA, M.; ZOCOLER, D.C. Manual de análises químicas de solo e controle de qualidade. Londrina: Instituto Agronômico do Paraná, 1992. 30p.

PIOVESAN, R.P.; FAVARETTO, N.; PAULETTI, V.; MOTTA, A.C.V.; REISSMANN, C.B. Perdas de nutrientes via subsuperfície em colunas de solo sob fertilização mineral e orgânica. Revista Brasileira de Ciência do Solo, Viçosa, MG, v.33, n.4, p.757-766, 2009.

SOIL SURVEY STAFF. Keys to soil taxonomy. $12^{\text {th }}$ ed. Washington: United States Department of Agriculture, 2014. 372p.

SORENSEN, P.; JENSEN, E. S. Mineralizationimmobilization and plant uptake of nitrogen as influenced by the spatial distribution of cattle slurry in soils of different texture. Plant and Soil, The Hague, v.173, n.1, p. 283-291, 1995.
TECCHIO, M.A., PAIOLI-PIRES, E.J., TERRA, M.M., TEIXEIRA, L.A.J., LEONEL, S. Características físicas e acúmulo de nutrientes pelos cachos de 'Niágara Rosada' em vinhedos na região de Jundiaí. Revista Brasileira de Fruticultura, Jaboticabal, v.29, n.3, p.621-625, 2007.

TECCHIO, M.A.; PAIOLI-PIRES, E.J.; TERRA, M.M.; GRASSI FILHO, H.; CORRÊA, J.C.; VIEIRA, C.R.Y.I. Correlação entre a produtividade e os resultados de análise foliar e de solo em vinhedos de Niágara Rosada. Ciência e Agrotecnologia, Lavras, v.30, n.6, p.1056-1064, 2006.

TEIXEIRA, L.A.J.; TECCHIO, M.A.; MOURA, M.F.; TERRA, M.M.; PIRES, E.J.P.; HERNANDES, J. L. Alterações em atributos químicos de um solo submetido à adubação e cultivado com videira 'Niágara Rosada'. Revista Brasileira de Fruticultura, Jaboticabal, v.33, n.3, p.983-992, 2011. 